\title{
A urine-powered cell, wheat straw and paper plaster walls: recyclable elements of a sustainable dwelling house
}

\author{
G. Luna-Sandoval ${ }^{1}$, C. F. Contreras-Flores ${ }^{1}$, P. Cruz-Camargo ${ }^{1}$, \\ M. Santacruz-Tirado ${ }^{1}$, E. Jiménez-López ${ }^{2}$, \\ V. H. Yaurima-Basaldúa ${ }^{1} \&$ M. A. Maciel-Monteon ${ }^{1}$ \\ ${ }^{1}$ Universidad Estatal de Sonora, México \\ ${ }^{2}$ Universidad La Salle Noroeste - CINNTRA de la UTS-IIMM, México
}

\begin{abstract}
To recover and recycle materials to be reused to build and operate a sustainable dwelling house is a new alternative using a urine-powered cell to produce hydrogen, wheat straw walls and paper plaster walls. Hydrogen from the urinepowered cell can be used as a biogas substituting conventional gas in stoves and boilers used to cook and heat water respectively. Constructing and applying wheat straw walls and paper plaster to obtain $\pm 10^{\circ} \mathrm{C}$ inside the rooms in winter and summer will provide a comfortable environment inside a dwelling house without air conditioning. Residents will save money by building sustainable dwelling houses and also will stop paying high energy bills. The environment and the general population will gain by using this alternative construction and operation system.
\end{abstract}

Keywords: urine, wheat straw, paper.

\section{Introduction}

To understand the functionality of this new premise for the 3 main recyclable elements used to build a sustainable dwelling house, this article presents the basic operation and characteristics of wheat straw, paper plaster and the urine-powered cell.

The advantages of wheat straw wall construction over conventional building systems include the renewable nature of wheat straw, cost, easy availability, 
naturally fire-resistant and a high insulation value. The disadvantages include susceptibility to rot, difficulty of obtaining insurance coverage and the large space requirements for the straw.

Research has been done using moisture probes placed within the straw walls, where 7 of 8 locations had a moisture content of less than $20 \%$. This is a moisture level that does not aid in the breakdown of the straw. However, proper construction of the straw-bale wall is important to keep moisture levels down, just as in the construction of any type of buildings.

Straw houses have been built on the African plains since the Paleolithic era, and were also used in construction 26 years ago in Germany. Straw-thatched roofs have long been used in northern Europe and Asia. In the New World, teepees were insulated in winter with loose straw between the inner lining and outer cover.

One important advantage of using wheat straw walls is that it will prevent the burning of fields after the wheat harvest, as shown in Figure 1.

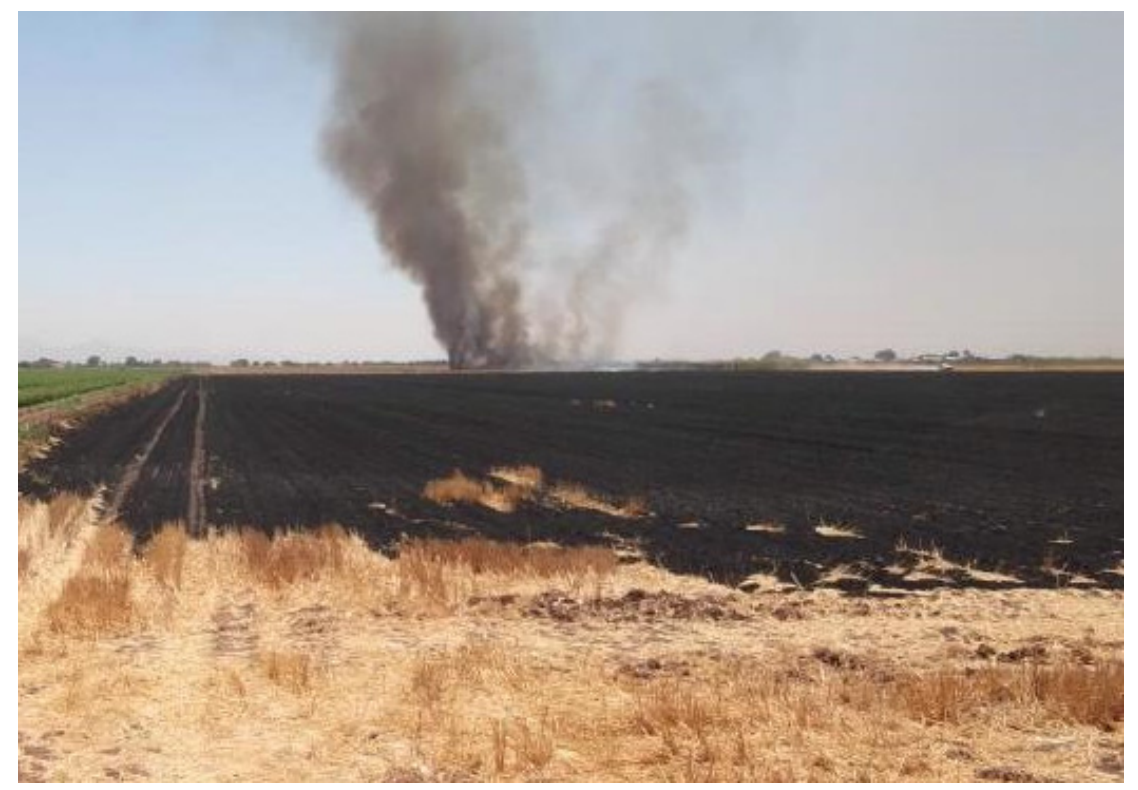

Figure 1: Air contamination from wheat straws burning fields.

The second sustainable material is paper plaster for the wheat straw walls, which will reduce the inside temperature of the rooms and give an insulation against the rain and sun. This is a new insulation technique used in México. Figure 2 show how paper plaster is applied to the wheat straw walls. In a conventional construction, it can be applied directly to the bricks or by using chicken wire for wood or drywalls. 


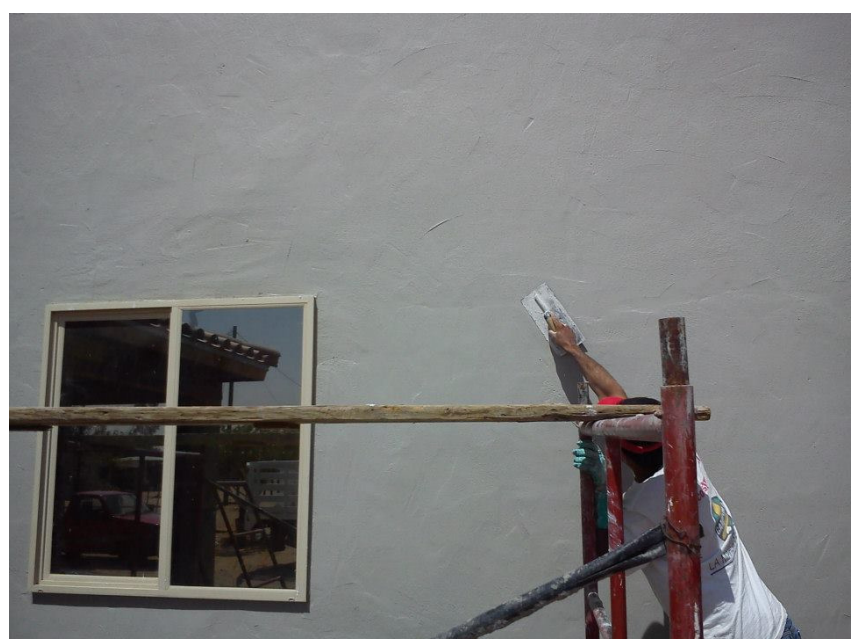

Figure 2: $\quad$ Paper plaster applied to a wheat straw wall.

The final sustainable material is urine. Urine is the most abundant organic waste on Earth and is mainly composed of water containing some salts. This means that $1,000 \mathrm{ml}$ of urine contains $95 \%$ water and $5 \%$ organic solids.

In terms of organic waste, urine contains $30 \mathrm{~g}$ of urea and other components. Salts contain $25 \mathrm{~g}$ of sodium positive ions and others, as well as negative chloride ions.

Urea incorporates four hydrogen atoms per molecule (six in urine, including the hydrogen in the water), and the hydrogen atoms in urine are not so strongly bonded as in the case of water molecules. Figure 3 shows the urine-powered cell (CCO), which is used to produce hydrogen and is used in stoves or boilers.

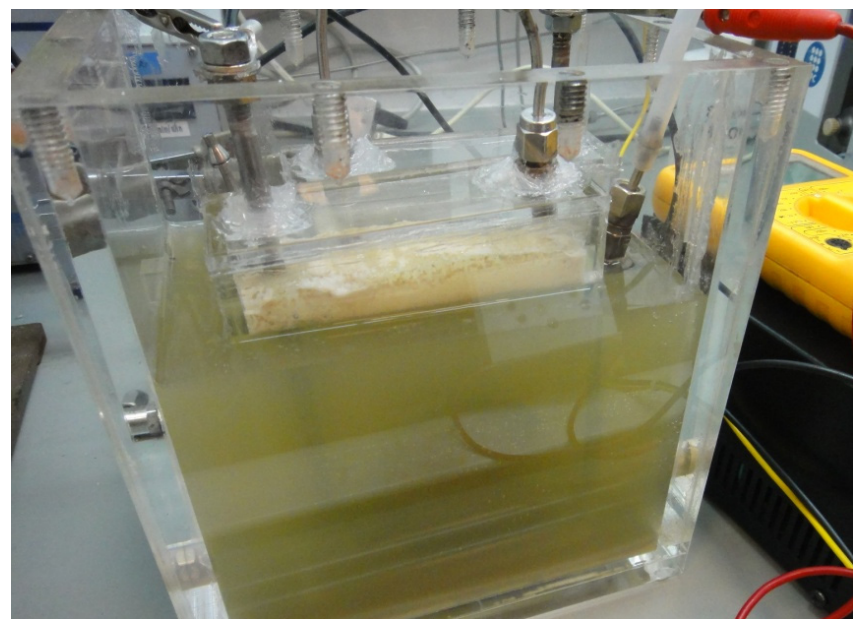

Figure 3: Hydrogen produced from a urine-powered cell. 


\section{Characteristics of the recyclable elements}

People should know the more relevant technical characteristics when considering these recyclable materials as construction and operation elements.

\subsection{Wheat straws walls}

When using wheat straws walls in the construction of a dwelling house, the following technical characteristics should be considered:

Wheat straw has a F90 fire resistance value, meaning that it has 90 minutes of resistance to fire, it has a $\mathrm{B} 2$ fire stability test (normal flammable), and a thermal conductivity of $\lambda_{\mathrm{R}}=0.0456 \mathrm{~W} / \mathrm{mK}$.

For isolated dwellings, the annual consumption for thermal conditioning is below $15 \mathrm{kWh} / \mathrm{m}^{2}$.

Wire is used to compact the wheat straw and convert it into a 2 square meter block. By stacking wheat straw blocks, the result will be a wall. But it is necessary to construct the structure of the house with normal construction materials.

\subsection{Paper plaster}

To include recycled paper as a thermal insulation to be used as paper plaster, the following should be considered:

Paper plaster reduces the temperature up to $12^{\circ} \mathrm{C}$, and it has a low thermal conductivity, $0.144<\mathrm{k}<0.1923 \mathrm{w} / \mathrm{mK}$.

Paper plaster does not have a fire propagating characteristic. Also it does not harbor animals or the creation of bacteria because it is a mineralized product.

Mixing recyclable newspaper with lime and other chemical additives will produce this paper plaster. Actually, this product is patent pending.

\subsection{Urine-powered cell}

Electrolysis in urine has more potentially important characteristics than water, it can produce more hydrogen. Table 1 shows a comparative between these 2 liquids.

Table 1: Comparison between water and urine electrolysis.

\begin{tabular}{|l|l|}
\hline \multicolumn{1}{|c|}{ Water } & \multicolumn{1}{c|}{ Urine } \\
\hline Molecule splits at 1.23 VDC & $\begin{array}{l}\text { Molecule splits at } 0.36 \\
\text { VDC }\end{array}$ \\
\hline 2 hydrogen molecules & 6 hydrogen molecules \\
\hline
\end{tabular}

To understand the process of producing hydrogen it is necessary to know the operation of the urine-powered fuel cell. It has 2 ANSY 316L electrodes in an acrylic storage box. 
Economic materials are being used to give the opportunity to all people with limited financial resources to build. The urine-powered cell is also patent pending.

The hydrogen produced can be used as a biogas for cooking in stoves and to heat water in the boilers.

\section{Conclusions}

The development and construction of a dwelling house results in some conclusions, which are summarized as follows:

The CCO was designed and constructed for operation in sustainable houses, converting urine into hydrogen and then used as a biofuel in internal stoves and boilers.

Using the $\mathrm{CCO}$ avoids storing hydrogen in tanks under pressure, because hydrogen remains in the urine until is ready to use. Storing hydrogen is dangerous because it is a highly flammable gas.

Both wheat straw walls and paper plaster reduce indoor temperatures by up to $12^{\circ} \mathrm{C}$, avoiding $\mathrm{A} / \mathrm{C}$ equipment.

Residential sustainable houses can be built with wheat straw walls up to 2 floors and comprises different architectural programs, such as single family homes, paired, borders, garages, sheds, kindergartens, schools, hospitals, public buildings or offices.

Sustainable houses can be insulated and plastered while reducing labor and material costs. This encourages recycling because waste materials such as newspapers, are used.

Hydrogen as a biogas can be used in stoves for cooking, and in boilers to heat water. We can take advantage of the urine cell as renewable energy.

\section{Acknowledgements}

This research was financially supported by Universidad Estatal de Sonora. The authors of this paper are grateful to universities that make up the SMEs Northwest Sonora Networks for their given support to this research.

\section{References}

[1] G. Luna-Sandoval, E, Jiménez-López , U. Luna-Rodríguez, R. ZepedaGonzález, M. Santacruz-Tirado, L. H. Hernández-Gómez, N. Luna-Acosta, Reverse Engineering Use in the Development of a Cell-Based Hydrogen Urine, International Journal of Mechatronics Design and Applications, Vol. 2(1), pp. 9-16, January 2013.

[2] W J. Larminie, "Fuel Cell Systems Explained", 2nd ed., Ed. John Wiley \& Sons Ltd, 2003, pp. 1-14.

[3] Erscheinungsort Wien, Building with renewable raw materials, Forschungs Forum, 4/2002.

[4] P. Cruz, Aislamiento Térmico Ecológico AhorroPel, www.facebook.com 